The Canadian Mineralogist

Vol. 38, pp. 1265-1281 (2000)

\title{
CHEMICAL SPECIATION OF GOLD IN ARSENOPYRITE
}

\author{
LOUIS J. CABRI ${ }^{\S}$ \\ Canada Centre for Mineral and Energy Technology, 555 Booth Street, Ottawa, Ontario K1A 0G1, Canada
}

MATTHEW NEWVILLE ${ }^{\S}$

Consortium for Advanced Radiation Sources, The University of Chicago, Chicago, Illinois 60637, U.S.A.

\section{ROBERT A. GORDON AND E. DARYL CROZIER}

Department of Physics, Simon Fraser University, Burnaby, British Columbia V5A 1S6, Canada, and PNC-CAT, Sector 20, Advanced Photon Source, Argonne National Laboratory, Argonne, Illinois 60439, U.S.A.

\section{STEPHEN R. SUTTON}

Consortium for Advanced Radiation Sources, The University of Chicago, Chicago, Illinois 60637, and Department of Geophysical Sciences, The University of Chicago, Chicago, Illinois 60637, U.S.A.

\section{GREG MCMAHON ${ }^{\mathbb{I I}}$}

Canada Centre for Mineral and Energy Technology, 568 Booth Street, Ottawa, Ontario K1A 0G1, Canada

\section{DE-TONG JIANG}

Department of Physics, Simon Fraser University, Burnaby, British Columbia V5A 1S6, Canada, and PNC-CAT, Sector 20, Advanced Photon Source, Argonne National Laboratory, Argonne, Illinois 60439, U.S.A.

\begin{abstract}
The speciation of Au in gold-bearing arsenopyrite (FeAsS) from four gold deposits (Olympiada, Sentachan, São Bento and Sheba) was determined by micro-X-ray absorption near-edge structure (XANES) on grains well characterized microscopically and by electron-microprobe and secondary-ion mass spectrometry analyses and images. "Invisible" gold in arsenopyrite occurs in two apparently mutually exclusive chemical forms: chemically bound and elemental. Arsenopyrite from the Sentachan, São Bento and Sheba deposits contains chemically bound gold. With comparable constituent electronegativities and a white-line feature in the XANES indicating unoccupied Au $5 d$-states, but absorption-edge positions comparable to $\mathrm{Au}^{1+}$ species, the bonding is interpreted as being covalent rather than ionic. The invisible gold in arsenopyrite from the Olympiada deposit, on the other hand, occurs as very small particles of $\mathrm{Au}^{0}$, probably less than a few nanometers in diameter. Micro-XANES data for the Olympiada and Sentachan arsenopyrite support earlier results obtained by ${ }^{197}$ Au Mössbauer spectroscopy on arsenopyrite concentrates. In some arsenopyrite crystals, the gold concentration is closely related to growth zoning. This feature represents conditions during crystallization and does not correlate with the chemical form of the gold. Similarly, selenium, where present, correlates with gold in some deposits and not in others, irrespective of the gold speciation. The finding of two types of invisible gold in arsenopyrite from different deposits has beneficial implications for extractive metallurgy.
\end{abstract}

Keywords: gold, arsenopyrite, micro-XANES, valence, X-ray microprobe, SIMS, EPMA.

\$E-mail addresses: 1cabri@sympatico.ca, newville@cars1.uchicago.edu

Il Present address: Fibics Incorporated, 556 Booth Street, Suite 200, Ottawa, Ontario K1A 0G1, Canada.

$\dagger \quad$ Present address: Canadian Light Source, University of Saskatchewan, 107 North Road, Saskatoon, Saskatchewan S7N 5C6, Canada. 


\section{SOMMAIRE}

Nous avons déterminé le mode d'incorporation de l'or dans l'arsénopyrite (FeAsS) provenant de quatre gisements d'or (Olympiada, Sentachan, São Bento et Sheba) par microstructure fine du seuil d'absorption X (XANES), cette analyse étant effectuée sur des grains bien caractérisés par microscopie, par analyses à la microsonde électronique et par spectrométrie de masse des ions secondaires (analyses et images). Dans l'arsénopyrite, l'or dit "invisible" est présent sous deux formes qui semblent mutuellement exclusives: chimiquement lié et en particules élémentaires. L'arsénopyrite des gisements de Sentachan, São Bento et Sheba contient l'or chimiquement lié. Avec des valeurs comparables de l'électronégativité des constituents et une bande blanche dans les spectres XANES indiquant des atomes d'or aux orbites $5 d$ non occupés, en même temps qu'un seuil d'absorption comparable à celui de l'espèce $\mathrm{Au}^{1+}$, le schéma de liaisons serait plutôt covalent qu'ionique. En revanche, l'or invisible du gisement d'Olympiada se présente sous forme d'infimes particules de $\mathrm{Au}^{0}$, d'un diamètre probablement inférieur à quelques nanomètres. Les données obtenues de concentrés d'arsénopyrite des gisements Olympiada et Sentachan par microanalyse XANES confirment les résultats obtenus antérieurement par spectroscopie de Mössbauer de l'isotope ${ }^{197} \mathrm{Au}$. Dans certains cristaux, la teneur en or semble étroitement liée à la zonation des cristaux. Cet attribut résulte de conditions spécifiques au cours de la cristallisation, et ne montre pas de corrélation avec la forme chimique de l'or. De même, le sélénium, où il est présent, montre une corrélation avec l'or dans certains gisements et non dans d'autres, quel que soit le mode d'incorporation de l'or. La découverte de deux modes d'incorporation de l'or invisible dans l'arsénopyrite a des implications bénéfiques en métallurgie de l'extraction.

(Traduit par la Rédaction)

Mots-clés: or, arsenopyrite, microanalyse XANES, valence, microsonde de rayons X, spectrométrie de masse des ions secondaires (SIMS), analyse à la microsonde électronique (EPMA).

\section{INTRODUCTION}

It is only in the last two decades that detailed characterization of submicroscopic or "invisible" gold in sulfide minerals became of interest for scientific and economic reasons, following the discovery of large lowgrade orebodies that can in some cases be mined by heap-leaching techniques. Some of these refractory gold ores occur in sediment-hosted gold deposits, typified by those in the area of Carlin, Nevada (Seabrook 1989). However, refractory gold ores also are found in many deposits worldwide, in different geological environments and ages (Boyle 1979). Early investigations into understanding how gold occurs in sulfides, beginning with those of Bürg (1930), have been reviewed by Cabri et al. (1989). The question of the chemical form of "invisible" gold in sulfide and sulfarsenide minerals has also attracted much interest in the last 12 years following the report of chemically bound Au in sulfides (Marion et al. 1986, Wagner et al. 1986). The term "invisible" arises as one cannot distinguish by conventional microscopy between gold chemically bound in the mineral and submicroscopic inclusions. The ore genesis and metallurgical implications for the presence of invisible gold in minerals such as arsenopyrite are potentially very significant (Mumin et al. 1994), and experimental techniques to determine the valence of gold in sulfides also are of current interest ( $\mathrm{Li}$ et al. 1995, Simon et al. 1999, Wagner et al. 1994). Experimental evidence, however, remains controversial because of low concentrations of gold, near the limits of resolution for conventional laboratory techniques, and its non-uniform distribution in sulfide minerals.

\section{REVIEW OF RECENT Work}

Among many papers on $\mathrm{Au}$ in arsenopyrite (FeAsS) since 1989, the following are relevant. On the basis of electron-probe microanalysis (EPMA), Johan et al. (1989) discussed substitution mechanisms in arsenopyrite from the Châtelet and Villeranges deposits (France). They proposed a substitution mechanism $2 \mathrm{As}[\mathrm{Fe}] \Leftrightarrow$ $(\mathrm{Au}, \mathrm{Sb})+\mathrm{Fe}$, where $\mathrm{As}[\mathrm{Fe}]$ is $\mathrm{As}$ on an Fe site. On the basis of the existence of $\mathrm{Fe}^{3+}$ in a non-polar state in the arsenopyrite structure (Buerger 1936), they suggested the presence of $\mathrm{Au}^{3+}$. Marcoux et al. (1989) mapped the distribution of $\mathrm{Au}$ in an arsenopyrite grain using EPMA in the Au-rich arsenopyrite from these two French deposits and also showed an inverse correlation between $\mathrm{Au}$ and Fe. Wu \& Delbove (1989) reported a negative correlation between levels of $\mathrm{Fe}$ and $\mathrm{Au}$ in synthetic arsenopyrite, suggesting substitution of Fe by Au. Their synthetic arsenopyrite crystals were found to be zoned, with a Au-rich rim and a Au-poor core. Wu et al. (1990) presented a ${ }^{197} \mathrm{Au}$ Mössbauer spectrum of synthetic arsenopyrite with peaks corresponding to a dominant chemically combined Au form (at $\sim+3.5 \mathrm{~mm} / \mathrm{s}$ ), as well as a minor peak representing $\mathrm{Au}^{0}$. In reviewing the relationship between crystal morphology and Au content for arsenopyrite crystals from some French deposits, they noted that the smaller, needle-shaped crystals are more likely to be Au carriers than larger pyramidal crystals, concluding that rapid crystallization might be a factor to promote Au-bearing arsenopyrite. Cook \& Chryssoulis (1990), in reviewing analyses of sulfide minerals by secondary ion mass spectrometry (SIMS), concluded that $\mathrm{Au}$ is found preferentially in the arsenopyrite struc- 
ture and may concentrate significantly in the finer grainsize, where two generations of arsenopyrite are present. However, there are exceptions to this correlation. Aylmore et al. (1993) used atomic location by channeling-enhanced microanalysis (ALCHEMI) to determine the location of $\mathrm{Au}$ within synthetic arsenopyrite. After confirming by electron diffraction that the basic structure of arsenopyrite is monoclinic $P 2{ }_{1} / c$ (Fuess et al. 1987), they examined the partitioning of Au between the Fe site and the $(\mathrm{As}+\mathrm{S})$ sites along the [101] zone axis. They found no significant correlation, concluding that a high percentage of the gold occurs either as fine inclusions or is located in a lattice defect or interstitial site. The purpose of our study was to use a number of different techniques, including EPMA, SIMS and micro-X-ray absorption near-edge structure (XANES), to characterize arsenopyrite in order to understand how the $\mathrm{Au}$ is contained within the minerals. It should be noted that this is the first report of micro-XANES studies done on a gold-bearing mineral. The recent work of Simon $e t$ al. (1999) was done using a large beam on a concentrate of arsenian pyrite grains.

Arehart et al. (1993) quoted unpublished X-ray photoelectron spectroscopic (XPS) measurements to suggest that gold enters the arsenopyrite structure in an oxidized form as $\mathrm{Au}^{3+}$. Li et al. (1995) also reported results of XPS analyses of a mixed pyrite-arsenopyrite sample from the Jinya gold mine (China). They stated: "The inter-peak distance and relative intensity ratio are basically identical to the experimental values for $\mathrm{Au}^{0}$. There is no doubt they are $4 f_{7 / 2}$ and $4 f_{5 / 2}$ of gold, and the measured values for $4 f_{7 / 2}$ are conspicuously lower than the $84.0 \mathrm{eV}$ of $\mathrm{Au}^{0}$, being between 82.5 and 83.5 $\mathrm{eV}$, respectively. As can be seen from the standard data presently used for XPS analysis, values of electron binding energy for gold in the gold compounds listed are all above $84.0 \mathrm{eV}$. Measured data for gold-bearing compounds are conspicuously lower than binding energy data for other gold compounds in which the gold is known to be $\mathrm{Au}^{1+}, \mathrm{Au}^{3+}$ and $\mathrm{Au}^{0}$ (Fig. 2), thereby indicating that the gold in these compounds has neither zero valence nor has it lost its valence electron (showing as positive valence) but is in a state of having acquired a valence electron or sharing a valence electron with other elements. Consequently, we propose that gold in the crystal lattices of these compounds exists in a negativevalence state." This unusual assignment has not been confirmed, and it is conceivable that the reported lower $\mathrm{eV}$ values might be due to sample charging (D.J. Vaughan, pers. commun., 1997). In their study of adsorption and deposition of $\mathrm{Au}$ on pyrite surfaces, Mycroft et al. (1995) noted the need for careful interpretation of the XPS binding energy data. They showed that $\mathrm{Au} 4 \mathrm{f}_{7 / 2}$ binding energy is a function of not only oxidation state but also size of the Au particles.

The existence of both visible native gold and chemically bound gold in sulfide and sulfarsenide minerals has been reported for many mesothermal gold deposits and may be regarded as the rule (Oberthür et al. 1997). Oberthür et al. (1997) also reported that arsenopyrite crystals from different deposits in the Ashanti gold belt (Ghana) have an Au-rich rim and an Au-poor core. On the basis of spot analyses by secondary ion mass spectrometry with a beam $30 \mu \mathrm{m}$ in diameter, they noted an inhomogeneous $\mathrm{Au}$ distribution in crystals greater than $50 \mu \mathrm{m}$ in diameter. Fleet \& Mumin (1997) provided a review of earlier work on arsenopyrite and suggested that invisible $\mathrm{Au}$ in arsenopyrite from sediment-hosted deposits represents $\mathrm{Au}$ removed from ore fluids by chemisorption at As-rich, Fe-deficient surface sites and incorporated as a metastable solid-solution. They concluded that "the oxidation state of invisible gold $\left(\mathrm{Au}^{0}\right.$, $\mathrm{Au}^{1+}$ ) remains uncertain because the chemisorption process is intrinsically non-systematic in terms of crystalchemical parameters and does not result in definitive atomic substitution trends." In a study of invisible gold from the Campbell mine (Ontario), Tarnocai et al. (1997) also reviewed and discussed earlier results. They reported that $(\mathrm{As}+\mathrm{S})_{\text {atomic }}$ is relatively constant at $\sim 66$ at.\%, whereas the $(\mathrm{As} / \mathrm{S})_{\text {atomic }}$ value shows an increase in Au-rich rims. They concluded that Au substitutes for Fe, not As. They also suggested that such variations in As and S, together with Au content, would be highly unlikely if $\mathrm{Au}$ were to occur as very fine inclusions $\left(\mathrm{Au}^{0}\right)$. They concluded that the $\mathrm{Au}$ is likely structurally bound in arsenopyrite in their samples.

Genkin et al. (1998) studied arsenopyrite from four Siberian gold deposits using a variety of techniques (ore microscopy, instrumental neutron-activation analysis (INAA), SIMS, EPMA and ${ }^{197} \mathrm{Au}$ Mössbauer spectroscopy). They suggested that the gold-bearing arsenopyrite in the Olympiada deposit formed contemporaneously with halos of retrograde alteration controlled by shear zones, with deposition from a fluid through fluidrock interactions; the native gold was considered to have deposited later. Genkin et al. (1998) stated that Au occurs chemically bound in arsenopyrite as well as in the form of submicroscopic $\mathrm{Au}^{0}$ in the four deposits considered, with chemically bound $\mathrm{Au}$ dominant in three of the four deposits. It is difficult to deduce the manner in which gold is bonded to its neighbors (or to even know what these neighbors are) on the basis of ${ }^{197} \mathrm{Au}$ Mössbauer spectra. However, Genkin et al. (1998) stated that the ".... invisible gold cannot be bonded in either the linear two-fold coordination typical for the monovalent, or the planar fourfold coordination typical for the trivalent valence state (Bartunik et al. 1970, Parish 1982). The most appealing interpretation is that the gold replaces iron in both arsenopyrite and pyrite. In stoichiometric arsenopyrite, it would then be surrounded by a distorted octahedron of three As and three $\mathrm{S}$ atoms as nearest neighbors, but the actual number and arrangement of neighbors may vary owing to deviations from stoichiometry that are common in arsenopyrite (Bortnikov 1993) and possibly lead to disorder in the host lattice. ..... The absence of a substantial quadru- 
pole splitting of the Mössbauer line of chemically bound invisible gold in arsenopyrite and pyrite is to be expected if the gold occupies $\mathrm{Fe}$ sites, which have a rather symmetrical environment of six nearest As and S neighbors. If the gold replaces As in the $[\mathrm{AsS}]^{3-}$ molecular units, the absence of a substantial quadrupole splitting is difficult to understand. Moreover, the magnitude of the isomer shift of $\mathrm{Au}$ in arsenopyrite appears to confirm the replacement of iron (Friedl et al. 1995)."

Experimental studies on deposition of Au from solutions have produced conflicting results, with some suggesting deposition of $\mathrm{Au}^{3+}$ and $\mathrm{Au}^{1+}$ on sulfide surfaces followed by reduction to $\mathrm{Au}^{0}$ (Jean \& Bancroft 1985), and others that electrochemical deposition of $\mathrm{Au}$ on sulfide and sulfarsenide surfaces is important in deposition from solutions with the sulfides acting as cathodes in galvanic cells (Möller \& Kerstein 1994). On the other hand, Cardile et al. (1993) showed that significant $\mathrm{Au}^{0}$ is absent on sulfide substrates in their experiments. The gold on sulfide was interpreted to be present as $\mathrm{Au}^{1+}$ on the basis of comparison of Mössbauer data on the substrates with spectra for $\mathrm{Au}_{2} \mathrm{~S}$.

More recently, XANES and extended X-ray absorption fine structure (EXAFS) analyses on Au were made of arsenian pyrite $\left[\mathrm{Fe}(\mathrm{S}, \mathrm{As})_{2}\right]$ concentrates from the Twin Creeks deposit, northwestern Nevada (Simon et al. 1999). A beam of $15 \times 1 \mathrm{~mm}$ produced mixed spectra; each spectrum was fitted with a linear combination of three reference spectra. These authors concluded that $\mathrm{Au}$ is present in the arsenian pyrite as compounds of $\mathrm{Au}^{1+}$ (with coordination numbers 2 and 4 ) together with metallic $\mathrm{Au}^{0}$, and that the arsenic is present as $\mathrm{As}^{1-}$. The XANES spectra that show significant $\mathrm{Au}^{1+}$ in twofold coordination are reported to be similar to $\mathrm{Au}_{2} \mathrm{~S}$, suggesting that $\mathrm{Au}^{1+}$ is linearly bonded to two sulfide ligands. Thus the literature on Au in arsenopyrite between 1989 and 1999 indicates a broad agreement that Au correlates inversely with $\mathrm{Fe}$, but there is a wide range of interpretations on the $\mathrm{Au}$ speciation, ranging from $\mathrm{Au}^{1-}, \mathrm{Au}^{0}$, $\mathrm{Au}^{1+}$ and $\mathrm{Au}^{3+}$. Thus the speciation of gold in arsenopyrite is not well understood, in spite of intense studies over the last 12 or so years.

In the present paper, we report on a multifaceted investigation into the chemistry and speciation of invisible gold in five samples of arsenopyrite from four mesothermal deposits: the Olympiada and Sentachan deposits in Siberia, Russia (Genkin et al. 1998), the São Bento mine in Minas Gerais, Brazil (Steele et al. 2000) and the Sheba mine in the Transvaal, South Africa (Schouwstra \& De Villiers 1988, Cabri et al. 1989). The present study involves a detailed characterization of the arsenopyrite grains by traditional methods such as EPMA, and by more recently applied methods such as SIMS and micro-XANES. Because gold may be heterogeneously speciated, we considered it important to use a spatially resolved, species-sensitive analytical technique such as micro-XANES, in an attempt to obtain single-species data. This new study on individual grains of arsenopyrite, together with the XANES data on arsenian pyrite concentrates (Simon et al. 1999), provide a comparison of how invisible gold occurs in the two most important minerals present in refractory sulfide ores.

\section{SAMPLES AND TeChNiques OF THEIR CHARACTERIZATION}

The specific samples examined in this investigation were: (1) Olympiada sample O-4, grains 47, 61, 62 plus ten additional randomly chosen grains; sample O-5, grains 1 and 29, (2) Sentachan sample, grain 11, (3) São Bento sample, grain SPB-1, and (4) Sheba mine sample RPS-353, grain RPS-4. In addition, a grain of aurostibite $\left(\mathrm{AuSb}_{2}\right)$ from Olympiada sample $\mathrm{O}-4$ was examined using XANES. All the arsenopyrite samples (in the form of concentrates) had been mounted in polished sections and previously studied by ore microscopy, SEM, EPMA, ${ }^{197}$ Au Mössbauer spectroscopy and SIMS (Genkin et al. 1998). At different stages, some polished sections were lightly re-polished in order to reduce the SIMS craters.

In all cases, a preliminary examination was made at CANMET using reflected light microscopy to select suitable grains for analysis. The EPMA were done by wavelength-dispersion spectrometry at CANMET/ MMSL with a JEOL-733 electron microanalyzer, operated at $20 \mathrm{kV}$ and with a beam current of $20 \mathrm{nA}$ (cup reading), using the following $\mathrm{X}$-ray lines and standards: $\mathrm{Fe} K \alpha$ and $\mathrm{S} K \alpha$ (pyrite), CoK $\alpha$ (synthetic CoAsS), $\mathrm{As} K \alpha$ (synthetic $\mathrm{FeAs}_{2}$ ), $\mathrm{Ni} K \alpha$ and $\mathrm{Sb} K \alpha$ (synthetic $\mathrm{NiSb}$ ), $\mathrm{Cl} K \alpha$ (synthetic $\mathrm{NaCl}$ ), $\mathrm{P} K \alpha$ (apatite) and $\mathrm{Au} L \alpha$ (metal). The beam current was increased to $100 \mathrm{nA}$ and the counting time was $100 \mathrm{~s}$ for the Au analyses, in order to lower the minimum detection level (MDL) to 0.029 wt.\%. From five to eight spot analyses $(1-2 \mu \mathrm{m})$ were done on each grain ( $\mathrm{n}$ in Table 1). Corrections to the raw data were made using Armstrong's ZAF program.

The SIMS quantitative analyses and direct ion images were obtained at CANMET/MTL using procedures as described in Cabri \& McMahon (1995) and in McMahon \& Cabri (1998).

The XANES analyses were performed at the PNCCAT and GSE-CARS undulator beamlines, Sectors 20 and 13, respectively, at the Advanced Photon Source, Argonne National Laboratory (Heald et al. 1999, 2000, Newville et al. 1999, in prep., Sutton \& Rivers 1999).

Monochromatic X-rays were focused $(3 \mu \mathrm{m} \times 3 \mu \mathrm{m}$ spot, PNC; $10 \mu \mathrm{m} \times 10 \mu \mathrm{m}$ spot, CARS, penetration depth $\sim 5 \mu \mathrm{m}$ ) on the grains using a Kirkpatrick-Baez mirror pair (Eng et al. 1998). The samples were mounted on an XY translation stage to allow the focused beam to be positioned on any part of the sample. Fluorescent Xrays were detected using a multi-element germanium detector at the PNC-CAT beamline and using an Oxford WDX-600 wavelength-dispersion spectrometer at 
the GSE-CARS beamline (Rivers \& Sutton 1995, Smith $\&$ Rivers 1995). The germanium detector has the advantage of collecting the full fluorescence energy-spectrum and allowing multiple regions in that spectrum to be monitored during a scan, but it has a worse energy resolution $(200 \mathrm{eV}$ versus $20 \mathrm{eV})$ than the spectrometer. The spectrometer has the advantage of higher resolution of energy, allowing discrimination against $\mathrm{As} K \alpha$.

\section{RESULTS}

\section{Composition of the arsenopyrite grains studied}

The arsenopyrite grains were re-analyzed by EPMA, specifically within the same areas where the X-rays were focused for the XANES data. Four of the grains are shown in Figure 1, with the location of each EPMA indicated by $\mathrm{X}$ or numbers with respect to the still visible SIMS craters. The mean compositions for six grains are given in Table 1 . The complete dataset may be obtained from the Depository of Unpublished Data, CISTI, National Research Council of Canada, Ottawa, Ontario K1A 0S2. All the arsenopyrite grains have $S$ in excess of As and are metal-rich, with $M$ :[S,As] ranging from 1.006:1.994 for Sheba grain RPS-4 to 1.0244:1.984 for Olympiada grain 47.

Post-XANES SIMS ion images were taken of Olympiada (O-4) grains 47, 61 and 62 to show the spatial distribution of $\mathrm{Au}$ as well as the anticorrelation with Se (Figs. 2, 3). Two types of Au distribution are seen. On the one hand, the Au is closely related to the welldeveloped rhombdohedral growth-zones in arsenopyrite (Fig. 2, top), and on the other, the Au does not appear to be related to any obvious growth-zones, but rather oc-

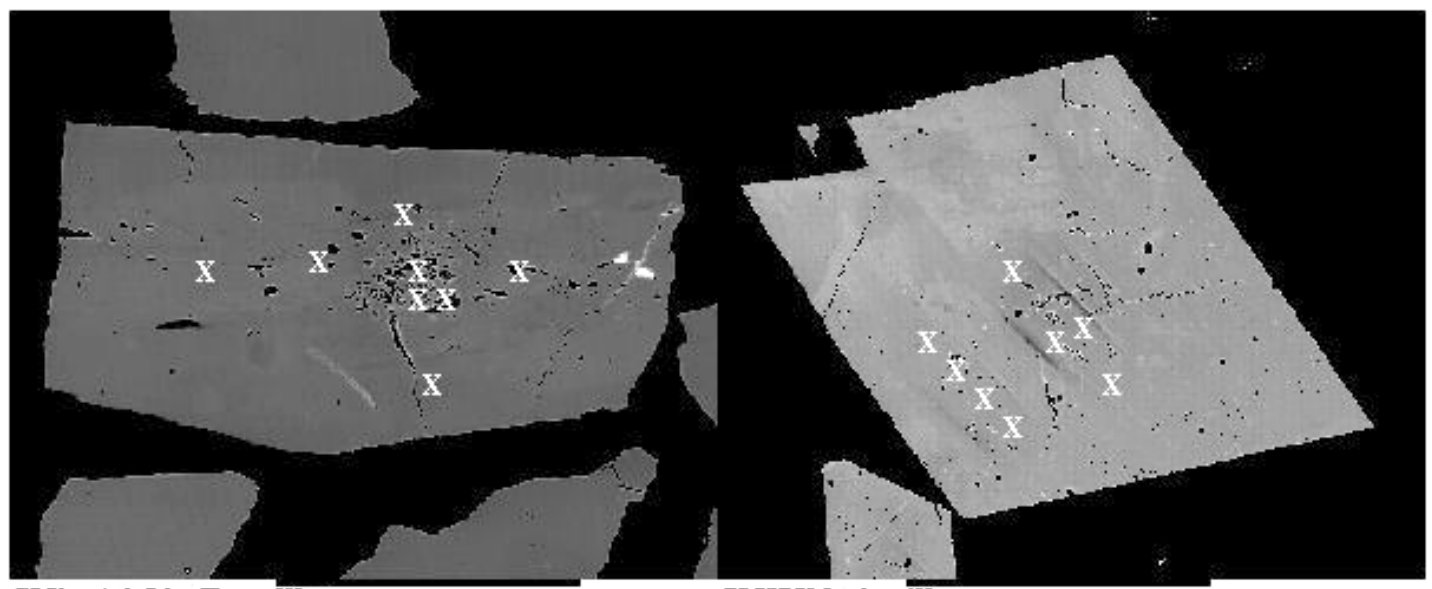

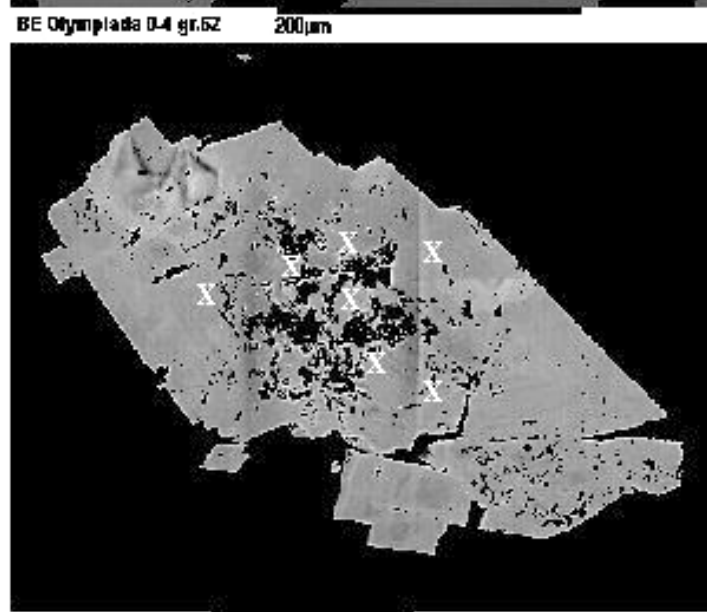

BE RPS3W AAp4
Tơm
BE SPBDE AEPA TODTh

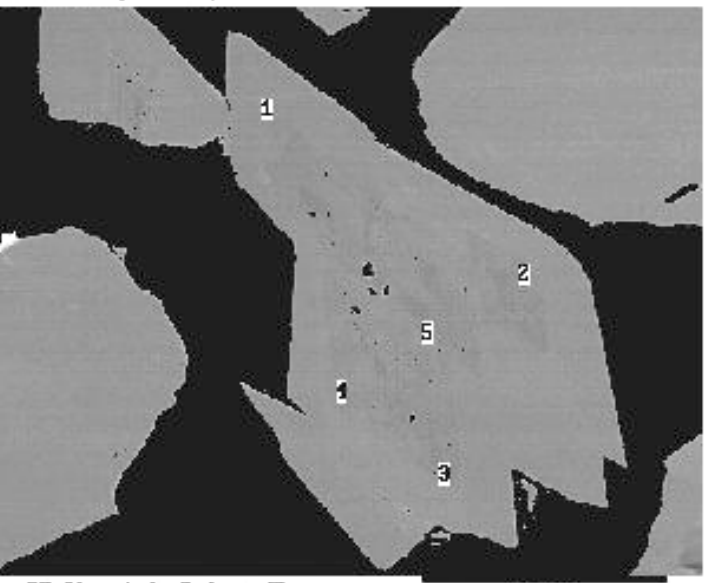

BR 0lypaisida B-4 gr.-5?
$10 \mathrm{gm}$

FIG. 1. Back-scattered electron images of four arsenopyrite grains with locations of EPMA indicated by an X or number. Remains of the SIMS sputter craters may be seen in three of the grains, even after a light re-polish. 
TABLE 1. SIMS AND ELECTRON-MICROPROBE COMPOSITIONS OF ARSENOPYRITE GRAINS

\begin{tabular}{|c|c|c|c|c|c|c|c|c|c|c|c|}
\hline Locality & grain & $\begin{array}{l}\text { SIMS Au } \\
\text { content } \\
\text { (ppm wt.) }\end{array}$ & $\begin{array}{c}\text { Range Au } \\
\text { EPMA } \\
\text { (wt.\%) }\end{array}$ & $\mathrm{n}$ & $\begin{array}{l}\mathrm{Fe} \\
\text { at. }^{*}\end{array}$ & $\begin{array}{l}\text { Co } \\
\text { at. }\end{array}$ & $\begin{array}{l}\mathrm{Ni} \\
\text { at. }\end{array}$ & $\begin{array}{l}\mathrm{Au} \\
\text { at. }\end{array}$ & $\begin{array}{l}\text { As } \\
\text { at. }\end{array}$ & $\begin{array}{l}\mathrm{Sb} \\
\text { at. }\end{array}$ & $\begin{array}{l}\mathrm{S} \\
\text { at. }\end{array}$ \\
\hline Oly $0-4$ & 47 & 2,298 & $0.00-0.13$ & 5 & 1.02 & 0.002 & 0.0004 & 0.002 & 0.90 & 0.004 & 1.08 \\
\hline Oly O-4 & 61 & 1,018 & $0.00-0.14$ & 8 & 1.02 & 0.002 & 0.0001 & 0.001 & 0.95 & 0.002 & 1.03 \\
\hline Oly O-4 & 62 & 810 & $0.00-0.09$ & 5 & 1.01 & 0.005 & 0.0002 & 0.002 & 0.95 & 0.001 & 1.03 \\
\hline Oly O-5 & 1 & 273 & $0.00-0.02$ & 5 & 1.01 & 0.002 & 0.0002 & 0.0003 & 0.88 & 0.002 & 1.11 \\
\hline Oly O-5. & 29 & 435 & $0.00-0.00$ & 5 & 1.01 & 0.001 & 0.0000 & 0.0000 & 0.88 & 0.0001 & 1.12 \\
\hline Sentachan & 11 & 328 & $0.00-0.02$ & 6 & 1.01 & 0.001 & 0.001 & 0.0002 & 0.91 & 0.001 & 1.08 \\
\hline São Bento & SPB-1 & 150 & $0.00-0.01$ & 8 & 1.02 & 0.001 & 0.000 & 0.0002 & 0.86 & 0.0000 & 1.12 \\
\hline Sheba & RPS-4 & 1,182 & $0.00-0.10$ & 8 & 1.00 & 0.001 & 0.004 & 0.001 & 0.92 & 0.0004 & 1.07 \\
\hline
\end{tabular}

* Based on a total of 3 atoms:(Fe,Co,Ni,Au $)_{x}(\mathrm{As}, \mathrm{Sb})_{y} \mathrm{~S}_{z}$.

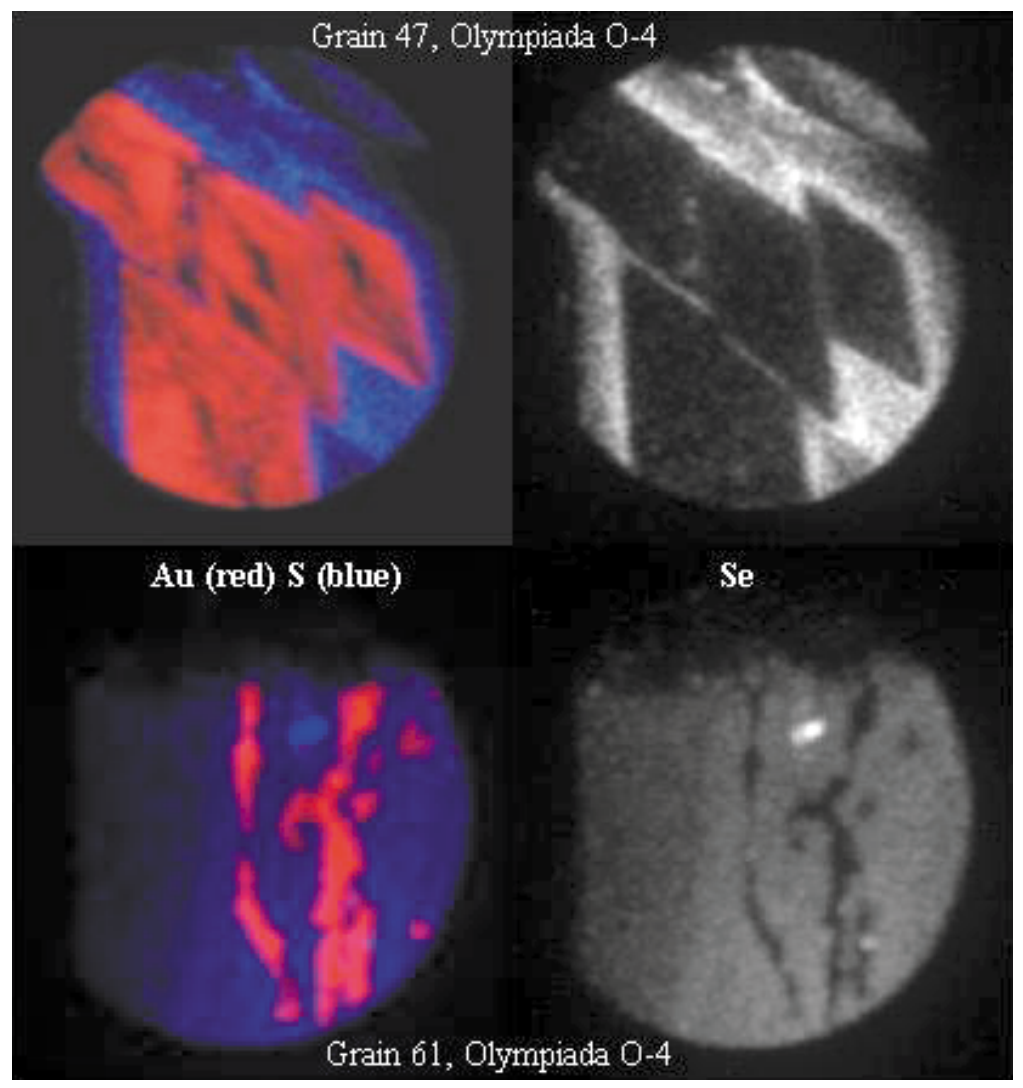

FIG. 2. SIMS ion images of two arsenopyrite grains from Olympiada $\mathrm{O}-4$. The field of view for the images is $62.5 \mu \mathrm{m}$ in diameter and is entirely within arsenopyrite for the upper two images. The Au is concentrated in the central parts of grain 47, closely following growth zones in rhombdohedral crystals with no Au in their centers. However, $\mathrm{Au}$ is also absent along the rim of the grain, and Se is concentrated in the Au-free zones. The two lower images represent the edges of grain 61 (seen at top and left of the lower images), showing again anticorrelation of Se and $\mathrm{Au}$. 


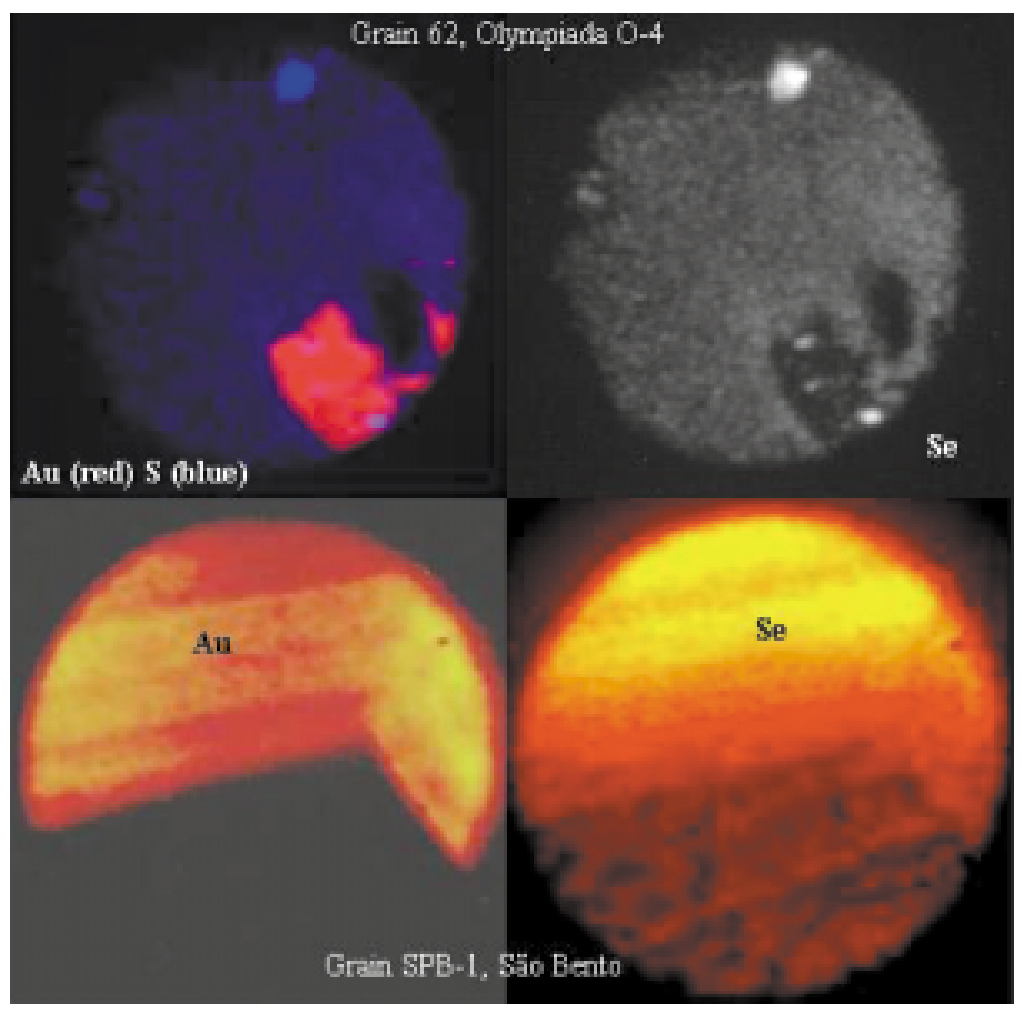

FIG. 3. SIMS ion images of arsenopyrite grain 62 from Olympiada O-4 (top) and for an arsenopyrite grain from the São Bento deposit (lower). The field of view for the images is $62.5 \mu \mathrm{m}$ in diameter and is entirely within arsenopyrite for all the images. The upper images show again anticorrelation of $\mathrm{Se}$ and $\mathrm{Au}$, whereas the lower images show correlation of Se and $\mathrm{Au}$.

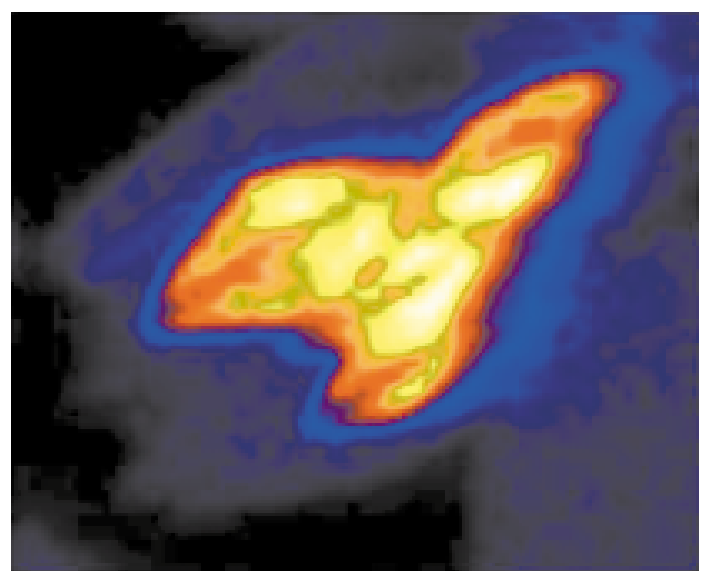

FIG. 4. X-ray-fluorescence map of the entire arsenopyrite grain 47 (Olympiada O-4), taken prior to the SIMS ion image shown in Figure 2 (for part of that grain). A $6 \times 7$ $\mu \mathrm{m}$ beam was used in 5- $\mu \mathrm{m}$ steps in $\mathrm{x}-\mathrm{y}$ direction, collecting the $\mathrm{Au}$ fluorescence for $2 \mathrm{~s}$. The incident energy was set to $12.0 \mathrm{keV}$, well above the Au edge. curs as Au-rich patches and lenticular zones (Fig. 2, lower, and Fig. 3, top). The Au concentration in Olympiada grain 47 was also mapped by X-ray fluorescence (Fig. 4), showing essentially the same spatial distribution related to growth zones in the SIMS ion image (Fig. 2), but at lower resolution. The grain from São Bento (SPB-1, Fig. 3) shows that the Au is closely related to growth zones, as was shown for several other grains of arsenopyrite from the same deposit (Steele $e t$ al. 2000). In contrast to the Olympiada grains, however, Se correlates positively with Au. The Au distribution in arsenopyrite from the Sheba mine shows a spatial relationship to the elongate morphology of the grain (Fig. 5). In this case, no Se was detected, and Ni has an irregular distribution, with some areas of high $\mathrm{Ni}$ in $\mathrm{Au}-$ poor zones. Grain 11 from the Sentachan deposit has a heterogeneous distribution of Au compared to the S distribution (Fig. 6), with no Se detected. 

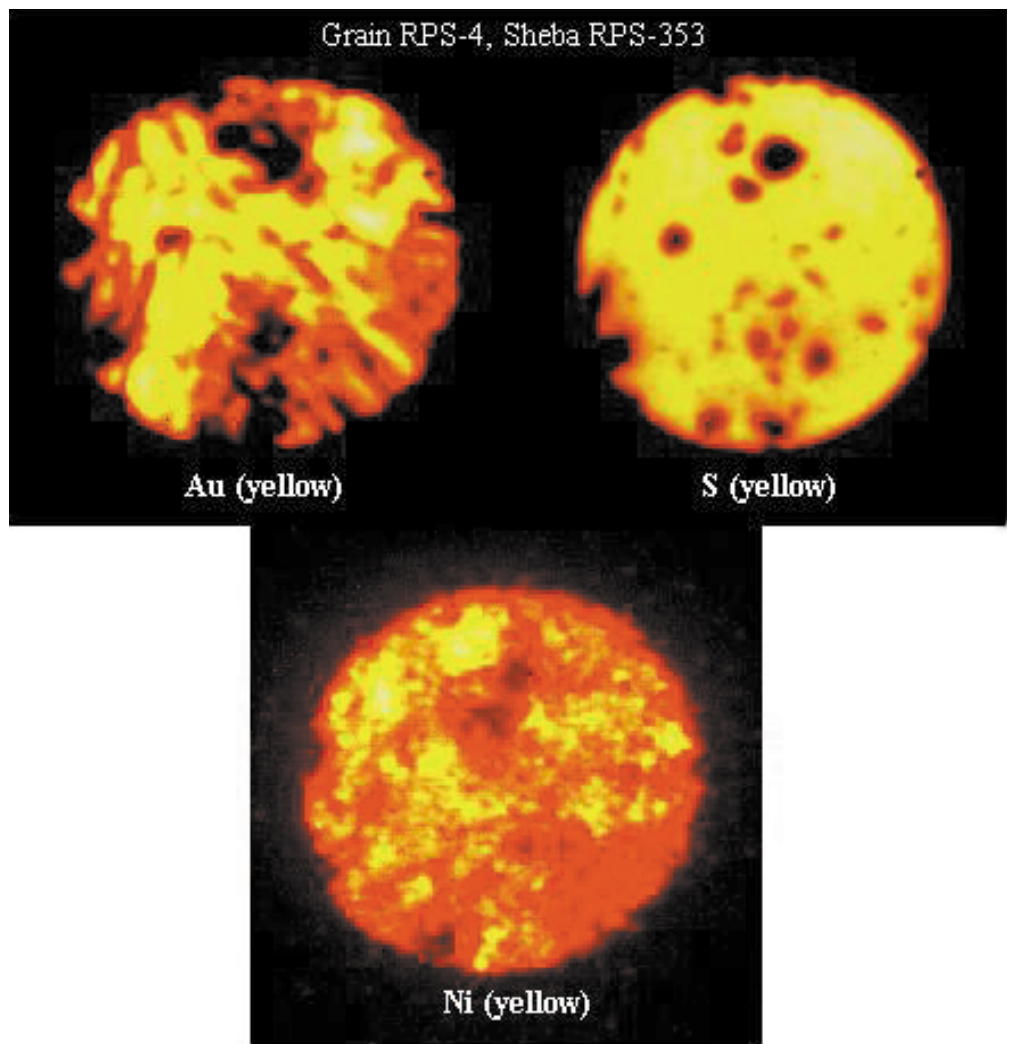

FIG. 5. SIMS ion images of an arsenopyrite grain from the Sheba mine. The field of view for the images is $62.5 \mu \mathrm{m}$ in diameter and is entirely within arsenopyrite for all the images. Black areas in the $\mathrm{S}$ image represent small non-sulfide mineral inclusions. No $\mathrm{Se}$ was detected. The Au is concentrated along the length of the elongate grain, whereas the $\mathrm{Ni}$ is distributed irregularly, with some of the Ni concentrated in Au-poor zones.

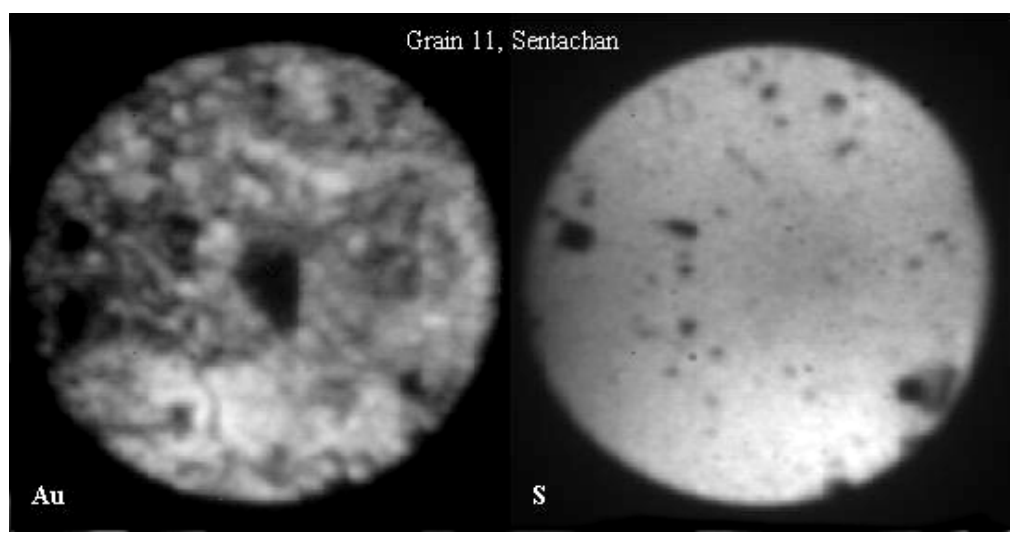

FIG. 6. SIMS ion images of arsenopyrite grain 11 from Sentachan. The field of view for the images is $62.5 \mu \mathrm{m}$ in diameter and is entirely within arsenopyrite for both images. The black areas in the $\mathrm{S}$ image represent small non-sulfide mineral inclusions. No Se was detected. The Au distribution is heterogeneous. 


\section{XANES data for arsenopyrite}

The XANES spectra were collected on three occasions, over an interval of several months. Data collected for $\mathrm{Au} L_{\mathrm{III}}$ XANES edge shifts and white line positions are given in Table 2. Edge shifts were determined from the peak of the first derivative of the spectra, with uncertainties based on the energy step-size and natural width of the absorption edge. We believe that the edge shift for arsenopyrite grain 47 (O-4, April data) is a little high, possibly because of the influence of the As background. In the case of the edge shift for the São Bento arsenopyrite, the 2.2 value may also be high because of the lower Au:As ratio (Table 1; see below, Fig. 13).

The proximity in energy of the AuL $\alpha$ and AsK $\alpha$ fluorescent lines presents a challenge in determining the chemical form of "invisible" gold with X-rays. The $K$ absorption edge of arsenic is $51 \mathrm{eV}$ below that of the gold $L_{\text {III }}$ edge. X-rays incident with sufficient energy to produce $\mathrm{Au} L \alpha$ fluorescent photons are also sufficiently energetic to produce fluorescence from arsenic, and from other elements $(\mathrm{Fe}, \mathrm{Ni}, \mathrm{Cu})$ with lower absorptionedge energies, as shown in the energy spectra from the multi-element detector (Fig. 7). At 10,543 eV, the AsK $\alpha$ fluorescence is centered $842 \mathrm{eV}$ above the $\mathrm{Au} L \alpha$ fluorescence $(9,711 \mathrm{eV})$, but has a tail into the gold region of the spectrum, giving a background to the gold signal.

Using the multi-element detector, the gold signal (with background) as a function of position is shown in Figure 8 for the Sheba arsenopyrite grain. The gold distribution, not surprisingly, is non-uniform, with a larger gold signal along the upper edge of the grain and in a spike in the left half. Compared to the SIMS region, the
TABLE 2. Au $L_{\text {III }}$ XANES EDGE SHIFTS AND WHITE LINE POSITIONS (eV) RELATIVE TO GOLD METAL

\begin{tabular}{|c|c|c|c|c|c|}
\hline $\begin{array}{l}\text { Mineral or } \\
\text { compound }\end{array}$ & $\begin{array}{c}\text { Edge } \\
\text { shift* } \\
\text { PNC } \\
\text { data }\end{array}$ & $\begin{array}{c}\text { Edge } \\
\text { shift* } \\
\text { CARS } \\
\text { data }\end{array}$ & $\begin{array}{c}\text { First } \\
\text { peak } \\
\text { PNC } \\
\text { data }\end{array}$ & $\begin{array}{c}\text { First } \\
\text { peak } \\
\text { CARS } \\
\text { data }\end{array}$ & $\begin{array}{c}\text { First } \\
\text { peak } \\
\text { Simon } \\
* *\end{array}$ \\
\hline Metallic gold & $0.0(0.5)$ & $0.0(0.5)$ & - & - & - \\
\hline $\mathrm{Au}^{3+} \mathrm{Cl}_{3} / \mathrm{NaAu}^{3+} \mathrm{Cl}_{4}$ & $-0.5(0.5)$ & - & $1.9(2)$ & - & 1.9 \\
\hline $\mathrm{Au}_{2}^{1+} \mathrm{S}$ & $0.9(0.5)$ & - & $4.2(2)$ & - & - \\
\hline Arsenopyrite (gr. 47, $0-4)+$ & $0.9(0.7)$ & $0.5(0.5)$ & - & - & - \\
\hline Arsenopyrite (gr. $47,0-4)++$ & - & $1.0(0.5)$ & - & - & - \\
\hline Arsenopyrite (gr. $62,0-4)$ & - & $0.0(0.5)$ & - & - & - \\
\hline Arsenopyrite (gr. 1, O-5) & - & $0.5(1.0)$ & - & - & - \\
\hline Arsenopyrite (gr. 29, 0-5) & - & $0.0(0.5)$ & - & - & - \\
\hline Arsenopyrite (São Bento) & - & $2.2(0.5)$ & - & $5.4(3)$ & - \\
\hline Arsenopyrite (Sheba) & $1.6(0.5)$ & $1.6(0.5)$ & $4.7(7)$ & $4.7(2)$ & - \\
\hline Arsenopyrite (Sentachan) & - & $1.0(0.5)$ & - & $3.0(1)$ & - \\
\hline Aurostibite $(0-4)$ & - & $0.0(0.5)$ & - & $3.0(1)$ & - \\
\hline Arsenian pyrite (Nevada) & - & - & - & - & 5.2 \\
\hline
\end{tabular}

* where 0.0 is defined as the position for the first inflection point, relative to $\mathrm{Au}$ metal.

** Position for Simon et al. (1999) data is estimated on the basis of a comparison of the standards gold metal and gold chloride.

+ April data; ++ November data.

edge region has $22 \%$ higher fluorescence signal, and the spike is $60 \%$ higher. The As fluorescence distribution (not shown) is similar, but more uniform, and shows only a $7 \%$ increase at the edge and no spike. The upper energy spectrum (A) shown in Figure 7 comes from the spike on the left, and the lower spectrum (B), from the region in the upper right, as indicated in Figure 8. XANES spectra for these two regions are shown in Figure 9, where a gold signal originating from absorption

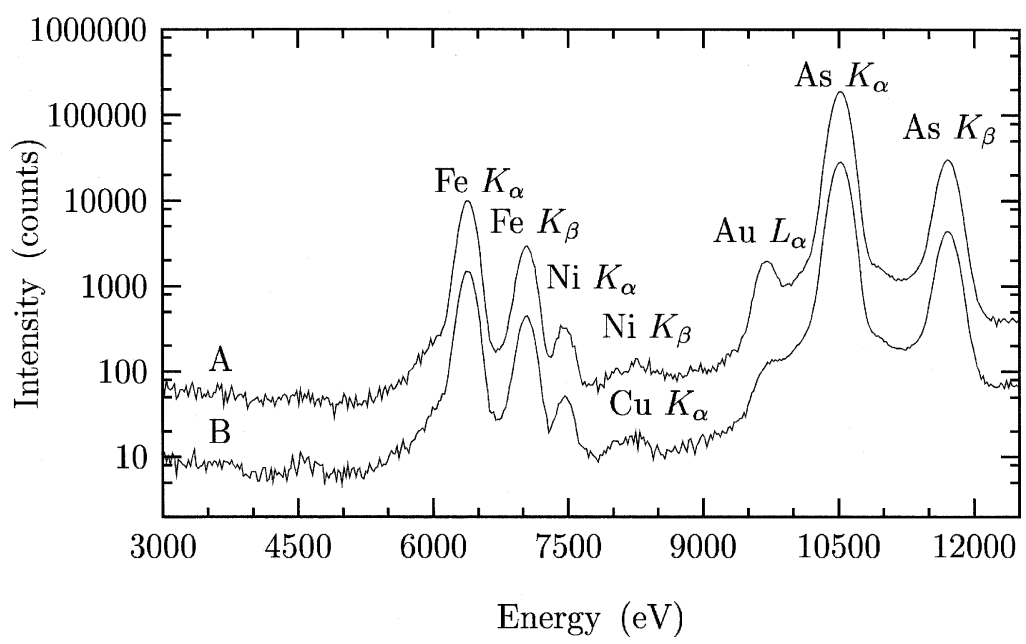

FIG. 7. X-ray-fluorescence spectra as a function of energy for regions A (upper curve) and B (lower) in the Sheba grain (Fig. 5). The lower curve was displaced from the upper by dividing by 5 . 


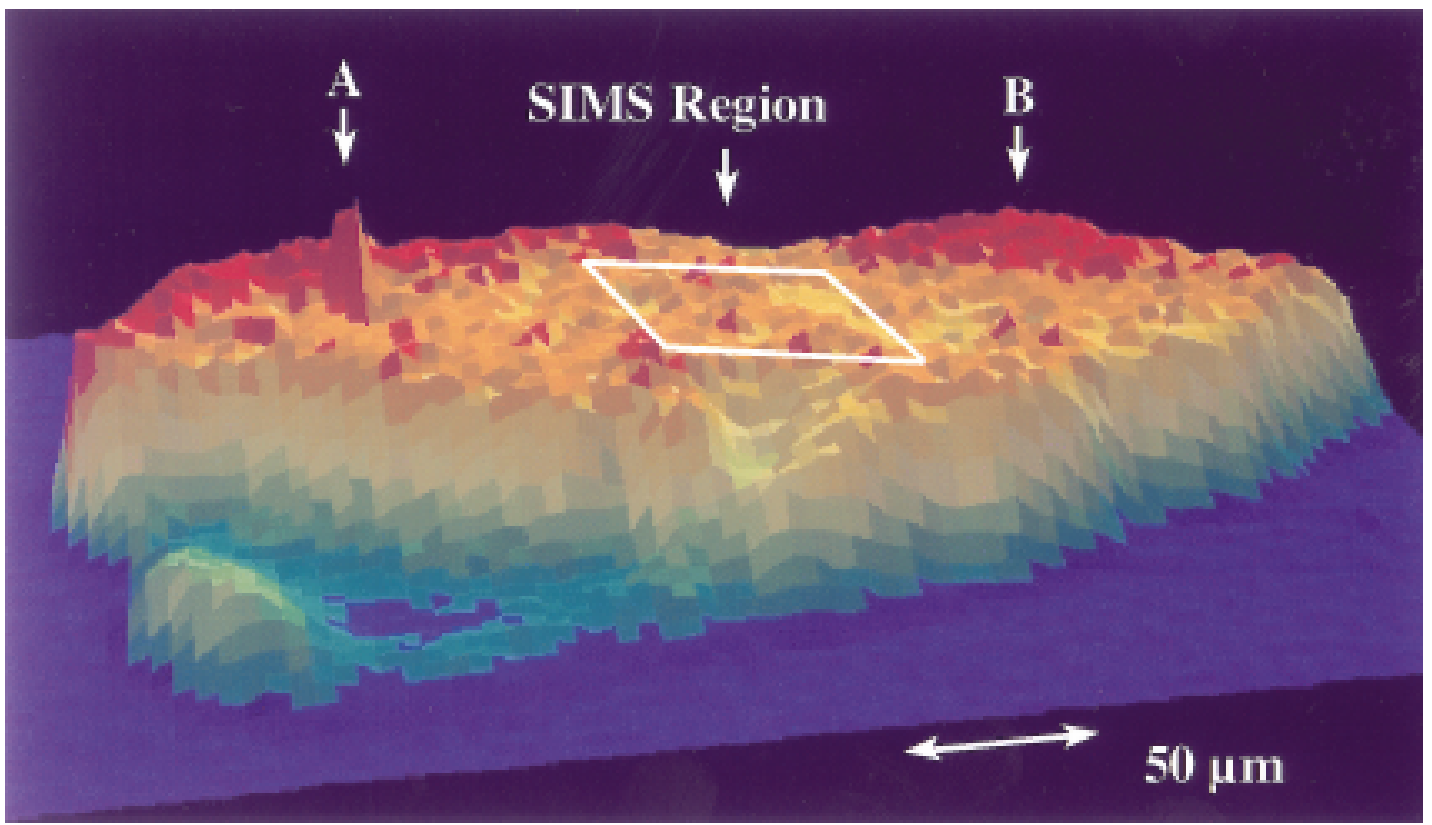

FIG. 8. Spatial dependence of the intensity of the gold region of the X-ray-fluorescence spectrum for an arsenopyrite grain from the Sheba sample. The region previously examined by SIMS (shown in Fig. 5, which contains 1,182 ppm Au) is outlined. Two regions (A, B) for which the X-ray spectra are displayed in Figure 7 are indicated.

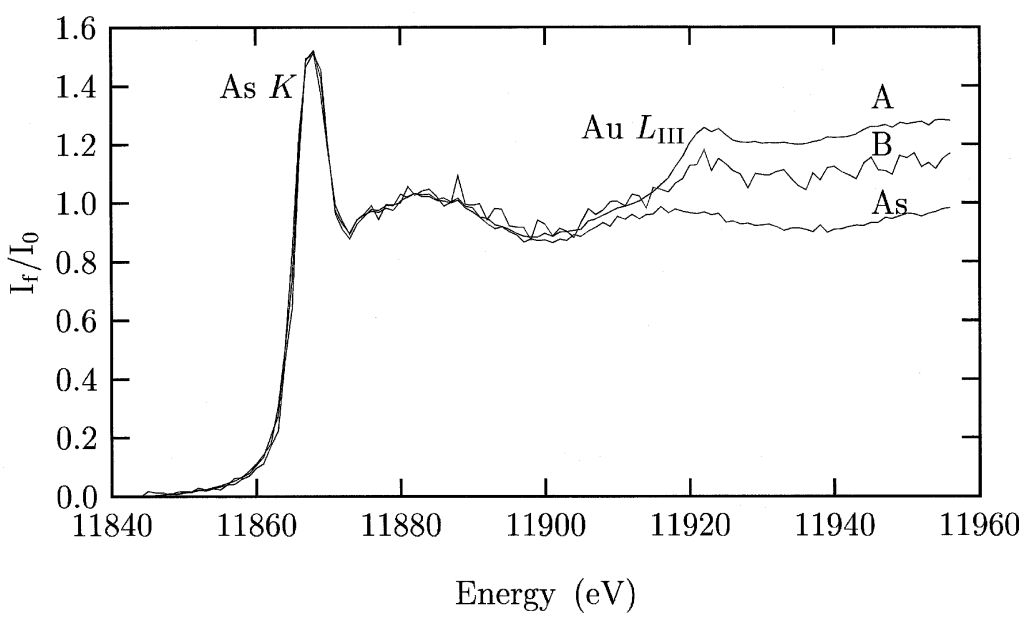

FIG. 9. XANES spectra from regions A and B of the Sheba grain. The arsenic background XANES was obtained from a gold-deficient region of an arsenopyrite grain from the Olympiada sample and found to be consistent with As XANES from the As region of the Sheba sample's X-ray spectrum. 


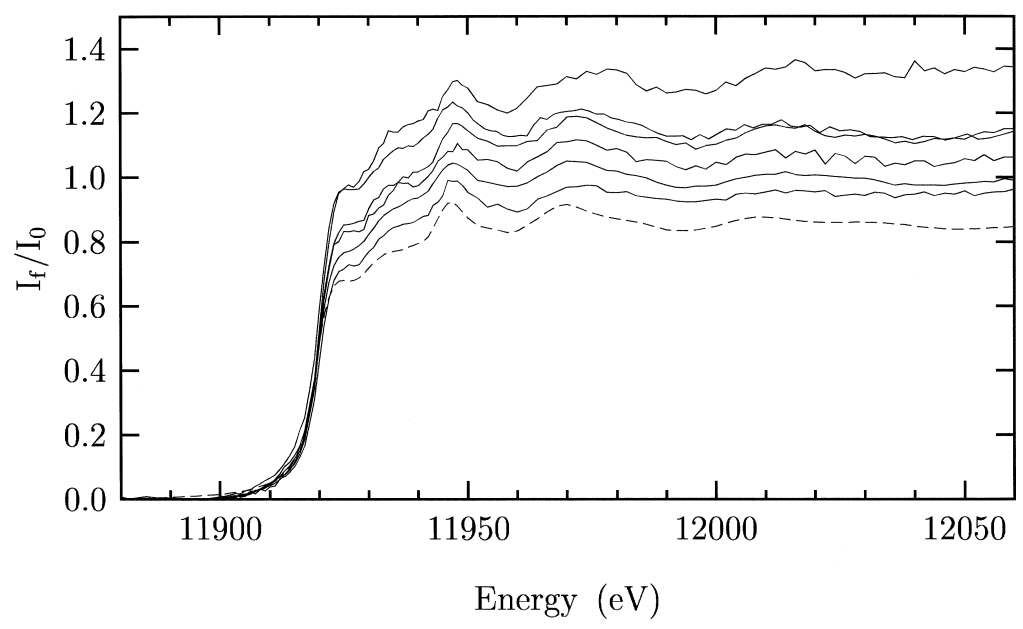

FIG. 10. Au XANES spectra taken from six randomly selected grains of arsenopyrite in sample Olympiada O-4, together with spectrum of metallic gold (foil) as a dashed line.

at the Au $L_{\text {III }}$ edge $(\sim 11,919 \mathrm{eV})$ is clearly discernible from the arsenic background arising from absorption at the arsenic $K$-edge $(\sim 11,868 \mathrm{eV})$. The XANES for region A (the spike) is an average of 28 scans, whereas that for region B is the result of just one scan (counting 5 seconds per point). The peak in the XANES evident just above the Au edge is a "white line" that arises from an appreciable number of unfilled gold $5 d$-states and suggests chemically bound $\mathrm{Au}$. We also recognize that the white line at the arsenic $K$-edge indicates the presence of unfilled As $4 p$-states.

\section{XANES spectra for arsenopyrite from Olympiada}

Genkin et al. (1998) determined by ore microscopy that native gold and aurostibite are both present in the sample from Olympiada (O-4), together with arsenopyrite. The arsenopyrite also contains invisible Au, over a wide range, from $69 \mathrm{ppb}$ to $2,298 \mathrm{ppm} \mathrm{Au} .{ }^{197} \mathrm{Au}$ Mössbauer data on an arsenopyrite concentrate from this sample showed that chemically bound gold amounts to $45 \pm 2 \%$ relative [ascribed to aurostibite, with an isomer shift (IS) $=+2.39 \pm 0.08]$ compared to $55 \pm 2 \%$ relative for metallic Au (Genkin et al. 1998). The SIMS analyses of individual arsenopyrite grains (then considered to represent mostly chemically bound gold), however, could not be correlated with the ${ }^{197} \mathrm{Au}$ Mössbauer spectroscopy, in terms of the proportion of Au attributed to chemically bound Au in arsenopyrite versus that attributed to gold chemically bound in aurostibite. The XANES for grain 47 from this sample, however, show no white line, and yet the $\mathrm{Au}$ in this grain is closely related to growth zones (Fig. 2, top). Though the polished section had been lightly re-polished to reduce the SIMS crater, some of the sputtered Au may have contributed to the metallic Au spectrum. Therefore, an additional seven randomly selected grains of arsenopyrite from this sample were scanned with WDS, but the Au XANES spectra once again show no white line (six spectra shown in Fig. 10). Following this result, a series of XANES scans were done at several points across grain 47; the composite of the scans is shown in Figure 11. Though noisy, the data are fairly similar, and none of the spectra show much evidence of a white line. The edge positions and lack of an intense white line below $\mathrm{E}$ $=11,940 \mathrm{eV}$ are consistent with the presence of metallic Au. Following this, grain 62 from the same sample was measured and gave a similar result (Fig. 11). An arsenopyrite concentrate from Olympiada sample O-5 contains a larger proportion of metallic gold $(79 \pm 9 \%)$, as determined by ${ }^{197} \mathrm{Au}$ Mössbauer spectroscopy (Genkin et al. 1998). However, in this case, no native gold or aurostibite was found by ore microscopy or SEM examination. Several Au XANES scans of arsenopyrite grains 29 (Fig. 12) and 1 from this sample showed again that the gold is metallic. Therefore all XANES measurements on arsenopyrite in the two Olympiada samples are consistent with metallic gold. No chemically bound gold was detected in the Olympiada arsenopyrite.

\section{XANES spectra on Sentachan arsenopyrite and aurostibite}

In order to find additional evidence of metallic $\mathrm{Au}$ versus chemically bound Au in arsenopyrite, XANES were measured in arsenopyrite grain 11 from Sentachan (Genkin et al. 1998). ${ }^{197}$ Au Mössbauer spectroscopy of an arsenopyrite concentrate from this sample indicated 


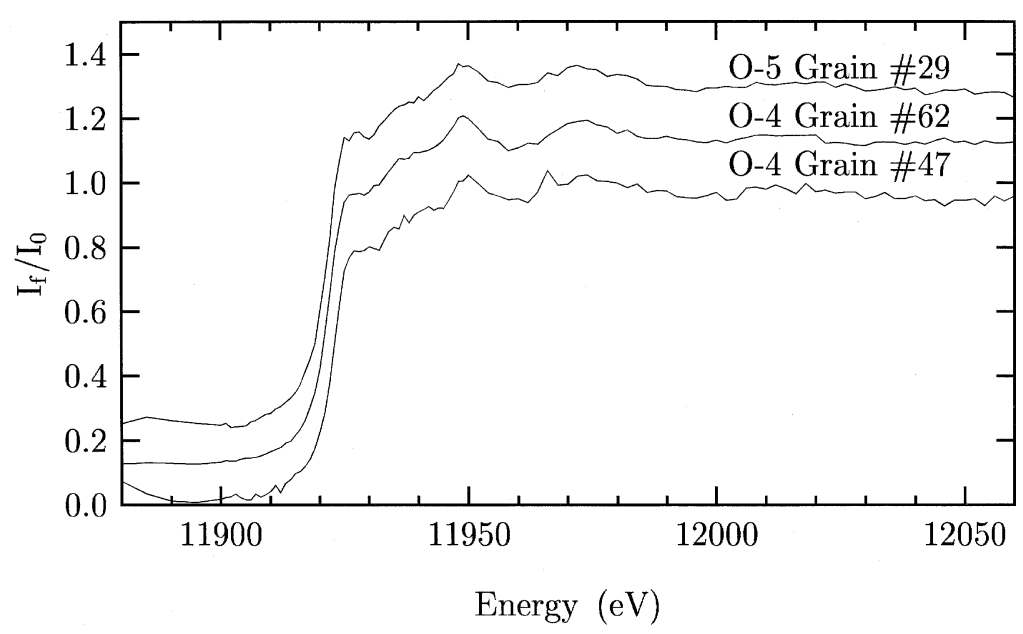

FIG. 11. A composite with Au XANES scans of three arsenopyrite grains from samples O-4 and O-5 (Olympiada). The spectrum for grain 47 is noisier because it represents the average of 25 scans on the grain from different points, with variable As concentrations.

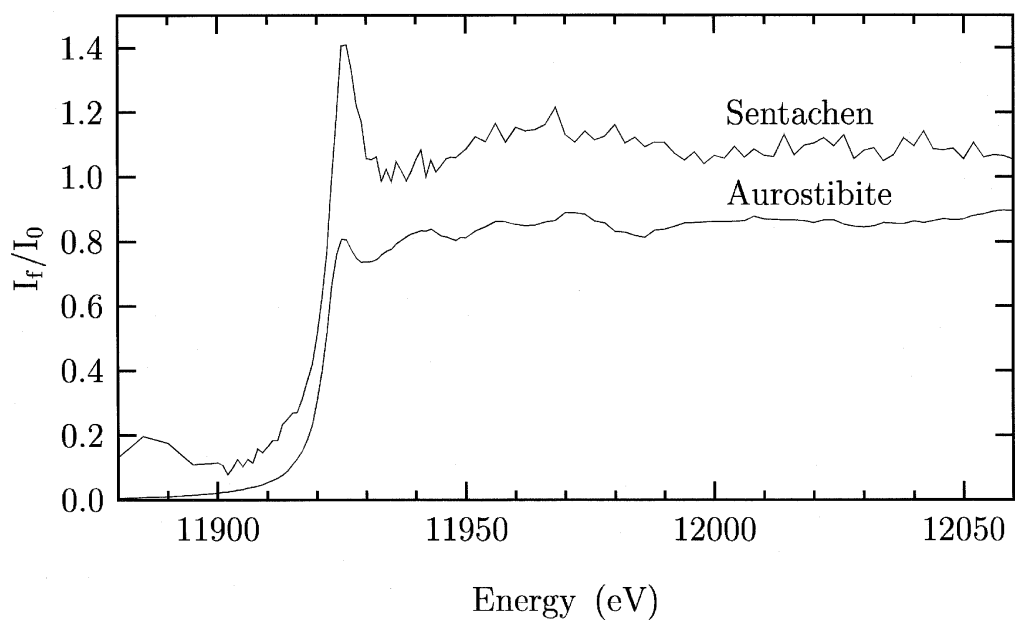

FIG. 12. Au XANES scans of arsenopyrite grain 11 (Sentachan) and of aurostibite (Olympiada O-4). The Sentachan spectrum is the average of 12 scans, and shows As $K$-edge XAFS below $11900 \mathrm{eV}$.

that $>95 \%$ of the Au was chemically bound, with an IS typical for sulfides and sulfarsenides (Friedl et al. 1992, 1995). For the XANES experiment, two locations just outside the SIMS crater were analyzed, and both spectra show a white line (Fig. 12). In addition, aurostibite in Olympiada sample $\mathrm{O}-4$ was analyzed, and the $\mathrm{Au}$ XANES spectrum also shows the expected white line (Fig. 12), clearly different from all the spectra of arsenopyrite in this sample (Fig. 11).

\section{Comparison of XANES spectra with reference standards}

In Figure 13, we show data from the WDX-600 spectrometer (with higher resolution of energy than the multi-element detector) for three samples, together with reference XANES spectra for $\mathrm{Au}$ foil, $\mathrm{Au}_{2} \mathrm{~S}$ and $\mathrm{AuCl}_{3}$ (in sealed ampoule) taken in transmission (foil) or fluorescence mode (sulfide, chloride) with ionization cham- 
bers. The latter represent $\mathrm{Au}^{0}, \mathrm{Au}^{1+}$ and $\mathrm{Au}^{3+}$, respectively (Pantelouris et al. 1995, Wagner et al. 1994). The XANES spectrum measured from a region $30 \mu \mathrm{m}$ in diameter with high $\mathrm{Au}$ fluorescence signal in an arsenopyrite grain from the Olympiada $\mathrm{O}-4$ sample strongly resembles the spectrum for elemental gold, as observed in the other Olympiada data above (Figs. 10, 11). Consideration of quadrupole splitting (QS) and IS for $\mathrm{Au}_{2} \mathrm{~S}$ (Wagner et al. 1994) puts this binary compound almost midway between $\mathrm{Au}^{1+}$ and $\mathrm{Au}^{3+}$, but because the XANES has no white line, few, if any, $5 d$-states are unoccupied. The XANES spectra from both the Sheba and São Bento samples clearly exhibit a peak at the $\mathrm{Au}$ absorption edge (white line), a feature indicating chemically bound gold, as did the XANES for arsenopyrite from the Sentachan sample (Fig. 12) and the aurostibite (Fig. 12). Although the Au absorption edges for the Sheba and São Bento spectra are at a comparable energy to that of $\mathrm{Au}_{2} \mathrm{~S}$, the differences in the XANES spectral shapes clearly show that the Au-bearing phases in these two samples are not dominated by $\mathrm{Au}_{2} \mathrm{~S}$ (Fig. 12, Table 2).

\section{Discussion AND CONCLUSIONS}

The Au XANES spectra of arsenopyrite from three deposits (Sheba, São Bento and Sentachan) show white lines at the Au absorption edge. The Au XANES microresolution data on a grain of Sentachan arsenopyrite are in agreement with the ${ }^{197} \mathrm{Au}$ Mössbauer bulk data on an arsenopyrite concentrate from the same sample, indicating $>95 \%$ chemically bound Au in arsenopyrite (Genkin et al. 1998). However, Au XANES spectra of arsenopy- rite grains from two well-characterized samples from the Olympiada deposit $(\mathrm{O}-4$ and $\mathrm{O}-5)$ are distinctly different, showing no white line, consistent with metallic gold (and with features also typical of metallic gold above the edge).

SIMS ion and XRF images of the grain with highest $\mathrm{Au}$ content indicate that the $\mathrm{Au}$ is closely related to growth zoning (Figs. 2, 4), whereas images of other arsenopyrite grains from Olympiada show that the $\mathrm{Au}$ occurs in lenticular zones (Fig. 2) and patches (Fig. 3). São Bento and Sheba arsenopyrite shows chemically bound Au related to growth zoning (Figs. 3, 5), whereas an arsenopyrite grain from Sentachan, which also has a white line, shows chemically bound $\mathrm{Au}$ with a heterogeneous distribution (Fig. 6). The chemically bound gold in these three deposits is not aurostibite, because no aurostibite was found. We conclude that the spatial distribution of $\mathrm{Au}$ in arsenopyrite is unrelated to the speciation of $\mathrm{Au}$. Correlation or anti-correlation of $\mathrm{Au}$ with $\mathrm{Se}$ is also unrelated to the speciation of $\mathrm{Au}$, suggesting that the Se replacement for $\mathrm{S}$ is independent of the incorporation of $\mathrm{Au}$ in arsenopyrite.

To understand the XANES results for arsenopyrite from Olympiada, which indicate $\mathrm{Au}^{0}$, it is necessary to review the earlier Mössbauer and SIMS data (Genkin et al. 1998). They ascribed the $+2.39 \pm 0.08 \mathrm{~mm} / \mathrm{s}$ IS for sample O-4 to aurostibite, whereas assignment of a weak component at $+2.00 \pm 0.64 \mathrm{~mm} / \mathrm{s}$ IS for sample $\mathrm{O}-5$ is more problematic. There is no mineralogical evidence that the ill-defined shoulder in the Mössbauer spectrum of $\mathrm{O}-5$ at $+2.00 \pm 0.64 \mathrm{~mm} / \mathrm{s}$ (indicating chemically bound $\mathrm{Au}$ ) represents aurostibite. However, it is possible that this isomer shift should indeed also be

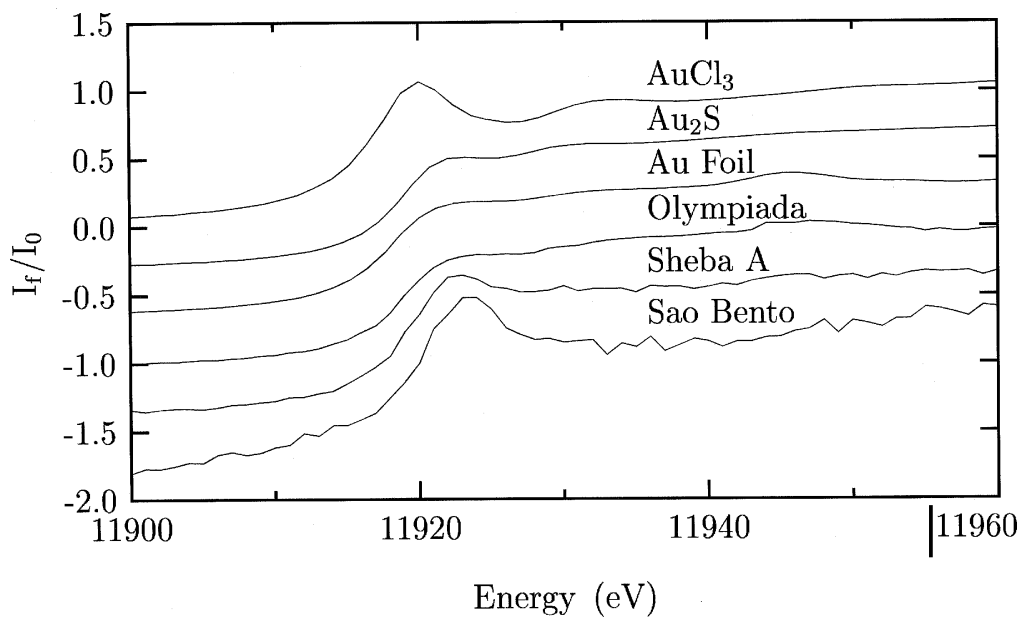

FIG. 13. Gold XANES spectra from three arsenopyrite grains and reference samples. Spectra have been displaced vertically for clarity. The ratio of the arsenic background to gold signal for the São Bento sample $(150 \mathrm{ppm} \mathrm{Au})$ is comparable to that of the data in Figure 9, taken with the Ge detector, whereas the ratios for the Olympiada and Sheba data, shown here for the spectrometer, are a factor of 10 better. 
considered to be due to aurostibite, which has an IS of $+2.33 \pm 0.02 \mathrm{~mm} / \mathrm{s}$ (Friedl et al. 1992). Fire assays of an arsenopyrite concentrate of sample $\mathrm{O}-5$ averaged $93.9 \mathrm{ppm}$, and 39 SIMS analyses of individual grains showed that the arsenopyrite contains an average of 77 ppm Au, representing $82 \%$ of the total Au (Genkin et al. 1998). Thus the invisible Au content of $82 \%$ (obtained by SIMS analyses) is very close to the $79 \pm 9 \%$ of the Au assigned as metallic from the Mössbauer data. It was also suggested by Genkin et al. (1998) that this metallic Au may in part represent submicroscopic gold, in particles as small as $2 \mathrm{~nm}$, which yield Mössbauer spectra that are practically identical to pure gold (Santucci et al. 1996, Stievano et al. 1998).

The XANES data with white lines, which provide evidence of chemical bonding of $\mathrm{Au}$ in arsenopyrite, may be interpreted in several ways (e.g., Simon et al. 1999). The absorption edge positions for the arsenopyrite samples occur near that for $\mathrm{Au}^{1+}$ compounds. Where electronegativities (EN) are comparable in a compound, one can expect a high degree of covalent interactions rather than ionic attractions (Pauling 1960). Such a case exists in gold-bearing arsenopyrite, where the $\mathrm{EN}$ of $\mathrm{Au}$, As and $\mathrm{S}$ differ by no more than 0.4 .

A better understanding of the electronic environment around gold in a mineral such as arsenopyrite might then be obtained by comparison with XANES and Mössbauer data done on intermetallic Au compounds. In the series of $\mathrm{Au} M_{2}$ compounds, where $M=\mathrm{Te}, \mathrm{Sb}, \mathrm{Sn}, \mathrm{In}$, $\mathrm{Ga}$, and $\mathrm{Al}$ (Sham et al. 1979, Bzowski et al. 1995), there is a $d$ to $s$ electron transfer, creating holes in the $d$ shell, but overall charge neutrality is largely maintained by $s$-electrons shifting from the ligands to the $\mathrm{Au}$. The $L_{\text {III }}$ XANES spectra see mainly the $d$ holes, and it is mainly the $s$-electrons that cause the Mössbauer shift. There is a linear correlation between the white-line areas at the Au $L_{\text {III }}$ edge $\left(\Delta A_{3}\right)$ or the change in number of $5 d$ holes at the Au site $\left(\Delta h_{t}\right)$ (obtained by XANES measurements) and the IS with respect to metallic Au (Table 3). Thus the IS increases proportionally to the number of $5 d$ holes (or white-line areas $\Delta A_{3}$ ), and this was explained as being due to Au forming hybridized bonds with its ligands (Sham et al. 1979). This effect reduces the number of $5 d$ electrons (from 10 in $\mathrm{Au}^{0}$ in $5 d^{10} 6 s^{1}$ configuration), and the holes thus created give rise to the white line. Similar results showing a white line was observed for broad-beam XANES on Au for concentrates of arsenian pyrite (Simon et al. 1999). The near-edge $\mathrm{Au} L_{\mathrm{III}}$ peak was described as a continuum resonance (Bianconi 1988) due to bound states (with $\mathrm{Au}$ $5 d$ character) at Au impurity sites. Simon et al. (1999) concluded that $\mathrm{Au}^{1+}$ could be concentrated in randomly distributed layers with a structure of marcasite or arsenopyrite, and that the $\mathrm{Au}^{1+}$ is probably incorporated into the arsenian pyrite structure by adsorption during crystal growth.

In the case of $\mathrm{Au}$ in arsenopyrite, there is some variability of the mean IS with respect to a Au:Pt source, but the IS cluster around $+3.5 \mathrm{~mm} / \mathrm{s}$ (Friedl et al. 1995), or $+4.7 \mathrm{~mm} / \mathrm{s}$ with respect to metallic gold. This latter value is closest to that for $\operatorname{AuIn}_{2}$ on the IS scale (Table 3), such that one might view the bonding in arsenopyrite to be similar to that of the Au intermetallic compounds. It is of interest to note that following the reasoning above, one would expect a smaller white line for aurostibite than for arsenopyrite since the IS with respect to $\mathrm{Au}$ are +3.56 and $+4.77 \mathrm{~mm} / \mathrm{s}$, respectively. Indeed, that was found to be the case (Fig. 12).

To describe gold chemically bound in the arsenopyrite structure in ionic terms as either $\mathrm{Au}^{3+}\left(5 d^{8}\right)$ or as $\mathrm{Au}^{1+}\left(5 d^{10}\right)$ appears to be inappropriate, since the position of the absorption edge rules out the former, and the peak due to unoccupied $5 d$-states rules out the latter, in agreement with Mössbauer data (Wagner et al. 1994). It is also relevant to refer to Figure 6 (QS versus IS for Au compounds) in Yang et al. (1998) [derived from Wagner et al. (1994), to which was added the range of chemically bound $\mathrm{Au}$ in sulfides]. The range (in the region $1.0<\mathrm{QS}<1.3 \mathrm{~mm} / \mathrm{s}$ ) lies well outside that of $\mathrm{Au}^{1+}$ and $\mathrm{Au}^{3+}$ compounds. In describing the valence of the constituent (chemically bound) elements in the goldbearing arsenopyrite, where comparable electronegativities indicate significant covalent interactions, one should not, in a strict sense, assign an ionic valence. We conclude, therefore, that a better though less satisfying description is to say that the gold is bound covalently.

By combining spatially selective micro-XANES and complementary analytical techniques, we have also shown that the invisible submicroscopic gold in arsenopyrite from four mesothermal gold deposits occurs in one of two ways: covalently or elementally, and the data suggest the gold speciation to be deposit-specific. The finding of two types of invisible gold was also reported for arsenian pyrite (Simon et al. 1999). However, the data for pyrite may be viewed as resulting from bulk analyses, whereas the present data on arsenopyrite pertain to individual grains. The distinction is important, as the pyrite data may come from two different populations of grains. We did not observe coexistence of metallic $\mathrm{Au}$ and chemically combined $\mathrm{Au}$ in our microbeam

TABLE 3. XANES- AND MÖSSBAUER-DERIVED PARAMETERS FOR Au INTERMETALLIC ALLOYS

\begin{tabular}{lccc}
\hline Alloy & $\begin{array}{c}\Delta A_{3} \\
\text { (Bzowski } \text { et al. 1995) }\end{array}$ & $\begin{array}{c}\Delta h_{\mathrm{t}} \\
\text { (Bzowski } \text { et al. 1995) }\end{array}$ & $\begin{array}{c}\text { IS } \\
*\end{array}$ \\
\hline & & & \\
$\mathrm{AuAl}_{2}$ & 1.06 & 0.56 & $7.26^{1}$ \\
$\mathrm{AuGa}_{2}$ & 0.72 & 0.38 & $5.56^{2}$ \\
$\mathrm{AuIn}_{2}$ & 0.54 & 0.26 & $4.64^{2}$ \\
$\mathrm{AuSn}_{2}$ & 0.50 & 0.24 & $3.97^{2}$ \\
$\mathrm{AuSb}_{2}$ & 0.46 & 0.21 & $3.56^{3}$ \\
$\mathrm{AuTe}_{2}$ & 0.18 & 0.01 & $2.55^{4}$ \\
\hline
\end{tabular}

Sources: 1. F.E. Wagner, unpublished; 2. Sham et al. (1979); 3. Friedl et al. (1992); 4. Wagner et al. (1994). *: with respect to $\mathrm{Au}^{0}$. 
study of individual arsenopyrite grains. This finding suggests that the two forms of Au are mutually exclusive in the case of arsenopyrite, with direct implications on their genesis.

Further, finding two types of invisible gold in arsenopyrite is of importance to mineral processing and extractive metallurgy. Instead of using an empirical approach to metallurgical tests, extraction techniques can be improved and results better understood because it is likely that the invisible gold occurring as nanometersize $\mathrm{Au}^{0}$ will behave differently to the chemically bound Au. Important questions remain to be determined by micro-XANES on arsenopyrite from many gold deposits from different settings, well-characterized by other methods: how common is the occurrence of each type, and do other types also exist? In addition, X-ray absorption fine structure (XAFS) data can be used to determine the coordination, bond length and identities of neighboring atoms.

\section{ACKNOWLEDGEMENTS}

The Natural Sciences and Engineering Research Council of Canada supported this work financially through an operating grant and a Major Facilities Access grant. Experiments at the Advanced Photon Source, Argonne National Laboratory were also supported by the United States Department of Energy, Basic Energy Sciences, under grants to the Pacific Northwest Consortium (PNC) [grant DE-FG03-97ER45628] and the Consortium for Advanced Radiation Sources (CARS) [grant DE-FG02-94ER14466] Collaborative Access Teams and the Advanced Photon Source (contract W31-109-Eng-38). The National Science Foundation under contract EAR-9317772 also supported experiments at CARS. L.J.C. is grateful to J.H.G. Laflamme (CANMET) for the EPMA, to Professor F.E. Wagner (Munich) for numerous helpful discussions, and for research support from CANMET/MMSL and the NRCan Synchrotron Committee. Finally, we are grateful for the helpful comments of referee F.E. Wagner, Associate Editor N.J. Cook and Editor R.F. Martin.

\section{REFERENCES}

Arehart, G.B., Chryssoulis, S.L. \& Kesler, S.E. (1993): Gold and arsenic in iron sulfides from sediment-hosted disseminated gold deposits: implications for depositional processes. Econ. Geol. 88, 171-185.

Aylemore, M.G., Graham, J. \& Johnson, A.W.S. (1993): The nature of gold in pyrite and arsenopyrite determined using ALCHEMI. In Mineralogy in the Service of Mankind (B. Griffin, J. Graham \& H. Linge, eds.). Proc. ICAM'93, 66-69.

Bartunik, H.D., Potzel, W., Mössbauer, R.L. \& Kaindl, G. (1970): Resonance spectroscopy of $\gamma$-radiation on $\mathrm{Au}(\mathrm{I})$ and $\mathrm{Au}(\mathrm{III})$ compounds. Z. Physik 240, 1-16.
BiAnCONI, A. (1988): X-ray absorption: principles, applications, techniques of EXAFS, SEXAFS and XANES. In XANES Spectroscopy (D.C. Koningsberger \& R. Prins, eds.). John Wiley \& Sons, Inc., New York, N.Y. (573-662).

BORTNIKOV, N.S. (1993): On a validity of the arsenopyrite and arsenopyrite-sphalerite geothermometers. Geol. Ore Deposits 35, 177-191.

BoyLe, R.W. (1979): The geochemistry of gold and its deposits. Geol Surv. Can., Bull. 280.

BuERGER, M.J. (1936): The symmetry and crystal structure of minerals of the arsenopyrite group. Z. Kristallogr. 95, 83113.

BÜRG, G.H. (1930): Die Sichtbarmachung des feinverteilten Goldes in goldhaltigen Erzen und ihre wirtschaftliche Bedeutung. Metall und Erz 27, 333-338.

Bzowski, A., Yiu, Y.M. \& Sham, T.K. (1995): Charge redistribution in Au-metalloid intermetallics: a Au $\mathrm{L}_{2,3}$-edge Xray-absorption study. Phys. Rev. B 51, 9515-9520.

Cabri, L.J., Chryssoulis, S.L., De Villiers, J.P.R., LAFLAMme, J.H.G. \& BuSECK, P.R. (1989): The nature of "invisible" gold in arsenopyrite. Can. Mineral. 27, 353362.

\& McMahon, G. (1995): SIMS analysis of sulfide minerals for Pt and Au: methodology and Relative Sensitivity Factors (RSF). Can. Mineral. 33, 349-359.

Cardile, C.M., Cashion, J.D., McGrath, A.C., Renders, P. \& SEWARD, T.M. (1993): ${ }^{197} \mathrm{Au}$ Mössbauer study of $\mathrm{Au}_{2} \mathrm{~S}$ and gold adsorbed onto $\mathrm{As}_{2} \mathrm{~S}_{3}$ and $\mathrm{Sb}_{2} \mathrm{~S}_{3}$ substrates. Geochim. Cosmochim. Acta 57, 2481-2486.

Cook, N.J. \& Chryssoulis, S.L. (1990): Concentrations of "invisible gold" in the common sulfides. Can. Mineral. 28, $1-16$.

ENG, P.J., NewVILle, M., Rivers, M.L. \& SutTon, S.R. (1998): Dynamically figured X-ray Kirkpatrick-Baez mirror-focusing optics. In X-Ray Microfocusing: Applications and Technique (I. Mcnulty, ed.). Proc. Soc. Photo-Opt. Instrum. Eng. 3449, 145-146.

FleEt, M.E. \& Mumin, A.H. (1997): Gold-bearing arsenian pyrite and marcasite and arsenopyrite from Carlin Trend gold deposits and laboratory synthesis. Am. Mineral. 82, 182-193.

Friedl, J., Wagner, F.E., Sawicki, J.A., Harris, D.C., MANDARINO, J.A. \& MARION, P. (1992): ${ }^{197} \mathrm{Au},{ }^{57} \mathrm{Fe}$ and ${ }^{121} \mathrm{Sb}$ Mössbauer study of gold minerals and ores. Hyperfine Interact. 70, 945-948.

\& WANG, N. (1995): On the chemical state of combined gold in sulfidic ores: conclusions from Mössbauer source experiments. Neues Jahrb. Mineral., Abh. 169, 279-290. 
Fuess, H., Kratz, T., TöPel-Schadt, J. \& Miehe, G. (1987): Crystal structure refinement and electron microscopy of arsenopyrite. Z. Kristallogr. 179, 335-346.

Genkin, A.D., Bortnikov, N.S., Cabri, L.J., Wagner, F.E., Stanley, C.J., SAfonov, Y.G., McMahon, G., Friedl, J., Kerzin, A.L. \& Gamyanin, G.N. (1998): A multidisciplinary study of invisible gold in arsenopyrite from four mesothermal gold deposits in Siberia, Russian Federation. Econ. Geol. 93, 463-487.

Heald, S.M., Brewe, D.L., Stern, E.A., Kim, K.H., Brown, F.C., JiANG, D.T., CrozIER, E.D. \& Gordon, R.A. (1999): XAFS and micro-XAFS at the PNC-CAT beamlines. $J$. Synch. Rad. 6, 347-349.

Stern, E.A., Brewe, D.L., Crozier, E.D., JiAnG, D.T., Gordon, R.A. \& Cross, J.O. (2000): XAFS at the PNC-CAT Undulator Beamline. J. Synch. Rad. (in press).

JEAN, G.E. \& BANCROFT G.M. (1985): An XPS and SEM study of gold deposition at low temperatures on sulphide mineral surfaces: concentration of gold by adsorption-reduction. Geochim. Cosmochim. Acta 49, 979-987.

Johan, Z., Marcoux, E. \& Bonnemaison, M. (1989): Arsénopyrite aurifère: mode de substitution de Au dans le structure de FeAsS. C.R. Acad. Sci. Paris 308, Sér. II, 185191.

Li, JiUling, Feng, Daming, QI, Jeng \& Zhang, Guilan (1995): The existence of the negative valence state of gold in sulfide minerals and its formation mechanism. Acta Geol. Sinica 69, 67-77.

Marcoux, E., Bonnemaison, M., Braux, C. \& Johan, Z. (1989): Distribution de Au, Sb, As et Fe dans l'arsénopyrite aurifère du Châtelet et de Villeranges (Creuse, Massif Central français). C.R. Acad. Sci. Paris 308, Sér. II, 293-300.

Marion, P., Regnard, J.-R. \& Wagner, F.E. (1986): Etude de l'état chimique de l'or dans des sulfures aurifères par spectroscopie Mössbauer de ${ }^{197} \mathrm{Au}$ : premiers résultats. C.R Acad. Sci. Paris 302, Sér. II, 571-574.

McMahon, G. \& CABRI, L.J. (1998): The SIMS technique in ore mineralogy. In Modern Approaches to Ore and Environmental Mineralogy (L.J. Cabri \& D.J. Vaughan, eds.). Mineral. Assoc. Can., Short Course 27, 199-224.

Möller, P. \& Kerstein G. (1994): Electrochemical accumulation of visible gold on pyrite and arsenopyrite surfaces. Mineral. Deposita 29, 404-413.

Mumin, A.H., FleEt, M.E. \& Chryssoulis, S.L. (1994): Gold mineralization in As-rich mesothermal gold ores of the Bogosu-Prestea mining district of the Ashanti Gold Belt, Ghana: remobilization of "invisible" gold. Mineral. Deposita 29, 445-460.

Mycroft, J.R., BANCRoft, G.M., MCInTYRE, N.S. \& LORIMER, J.W. (1995): Spontaneous deposition of gold on pyrite from solutions containing $\mathrm{Au}(\mathrm{III})$ and $\mathrm{Au}(\mathrm{I})$ chlorides. I. A surface study. Geochim. Cosmochim. Acta 59, 3351-3365.
Newville, M., Sutton, S.R., Eng, P.J. \& Rivers, M.L. (1999): Micro-beam XAFS, XRF, and XRD at APS 13-ID. J. Synchr. Rad. 6, 353-355.

Oberthür, T., Weiser, T., AmAnor, J.A. \& Chryssoulis, S.L. (1997): Mineralogical siting and distribution of gold in quartz veins and sulfide ores of the Ashanti mine and other deposits in the Ashanti belt of Ghana: genetic implications. Mineral. Deposita 32, 2-15.

PARISH, R.V. (1982): Gold and Mössbauer spectroscopy . Gold Bulletin 15(2), 51-63.

Pantelouris. A., Küper, G., Hormes, J., Feldmann, C. \& JANSEN, M. (1995): Anionic gold in $\mathrm{Cs}_{3} \mathrm{AuO}$ and $\mathrm{Rb}_{3} \mathrm{AuO}$ established by X-ray absorption spectroscopy. J. Am. Chem. Soc. 117, 11749-11753.

Pauling, L. (1960): The Nature of the Chemical Bond ( $3^{\text {rd }}$ ed.). Cornell University Press, Ithaca, N.Y.

Rivers, M.L. \& SutTON, S.R. (1995): A wavelength dispersive detector for synchrotron $\mathrm{x}$-ray fluorescence microprobe analysis. Rev. Sci. Instrum. 66, 1454 (abstr.).

SAntucci, S., Lozzi, L., Wagner, F.E. \& CAlogero, S. (1996): Preliminary ${ }^{197} \mathrm{Au}$ Mössbauer results concerning gold clusters produced by deposition of metallic gold on Mylar. In Proc. Int. Conf. on the Application of the Mössbauer Effect (I. Ortalli, ed.). Italian Phys. Soc. 50, 657-660.

Schouwstra, R.P. \& De Villiers, J.P.R. (1988): Gold mineralization and associated wallrock alteration in Main Reef Complex at Sheba mine, South Africa. Trans. Inst. Mining Metall., Sect. B 97, 158-170.

SeAbrook, T. (1989): A reporter at large. The New Yorker, April 24, 45-81.

Sham, T.K., Perlman, M.L. \& Watson, R.E. (1979): Electronic behaviour in alloys: gold - non-transition-metal intermetallics. Phys. Rev. B 19, 539-545.

Simon, G., Huang, Hui, Penner-Hahn, J.E., Kesler, S.E. \& KAO, LI-SHUN (1999): Oxidation state of gold and arsenic in gold-bearing arsenian pyrite. Am. Mineral. 84, 1071-1079.

Smith, J.V. \& Rivers, M.L. (1995): Synchrotron X-ray microanalysis. In Microprobe Techniques in the Earth Sciences (P.J. Potts, J.F.W. Bowles, S.J.B. Reed \& M.R. Cave, eds.). Chapman and Hall, London, U.K. (163-233).

Steele, I.M., Cabri, L.J., Gaspar, J.C., McMahon, G., MarqueZ, M.A. \& VAsconcellos, M.A.Z. (2000): Comparative analysis of sulfides for gold using SXRF and SIMS. Can. Mineral. 38, 1-10.

Stievano, L., Santucci, S., Lozzi, L., Calogero, S. \& WAGNER, F.E. (1998): ${ }^{197} \mathrm{Au}$ Mössbauer study of gold nanoparticles obtained by evaporation of metallic gold on mylar. J. Non-Cryst. Solids 232-234, 644-649.

SutTon, S.R. \& Rivers, M.L. (1999): Hard X-ray synchrotron microprobe techniques and applications. In Synchroton 
Methods in Clay Science (D.G. Schulze, J.W. Stucki \& P.M. Bertsch, eds.). Clay Mineral Soc., Workshop Lectures 6, 146-163.

TARnocai, C.A., Hattori, K. \& CABri, L.J. (1997): "Invisible" gold in sulfides from the Campbell mine, Red Lake greenstone belt, Ontario: evidence for mineralization during the peak of metamorphism. Can. Mineral. 35, 805-815.

Wagner, F.E., Marion, P. \& Regnard, J.R. (1986): Mössbauer study of the chemical state of gold in gold ores. In GOLD 100, Proc. Int. Conf. Gold 2 (Extractive Metallurgy of Gold). S. Afr. Inst. Mining Metall., 435-443.

Sawicki, J.A., Friedl, J., Mandarino, J.A., HARRIS, D.C. \& CABRI, L.J. (1994): ${ }^{197}$ Au Mössbauer study of the gold-silver ditellurides sylvanite, krennerite and calaverite. Can. Mineral. 32, 189-201.
Wu, Xin \& Delbove, F. (1989): Hydrothermal synthesis of gold-bearing arsenopyrite. Econ. Geol. 84, 2029-2032.

\& Touray, J.C. (1990): Conditions of formation of gold-bearing arsenopyrite: a comparison of synthetic crystals with samples from Le Châtelet gold deposit, Creuse, France. Mineral. Deposita 25, S8-S12.

Yang, Sixue, Blum, N., Rahders, E. \& Zhang, Zhenru (1998): The nature of invisible gold in sulfides from the Xiangi $\mathrm{Au}-\mathrm{Sb}-\mathrm{W}$ ore deposit in northwestern Hunan, People's Republic of China. Can. Mineral. 36, 1361-1372.

Received April 5, 2000, revised manuscript accepted September 17, 2000. 